\title{
Sulfanyl Porphyrazines with Morpholinylethyl Periphery-Synthesis, Electrochemistry, and Photocatalytic Studies after Deposition on Titanium(IV) Oxide P25 Nanoparticles
}

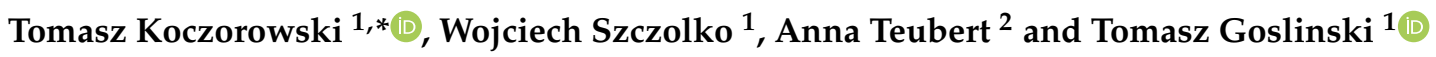 \\ 1 Chair and Department of Chemical Technology of Drugs, Poznan University of Medical Sciences, \\ Grunwaldzka 6, 60-780 Poznan, Poland; wszczolko@wp.pl (W.S.); tomasz.goslinski@ump.edu.pl (T.G.) \\ 2 Institute of Bioorganic Chemistry, Polish Academy of Sciences, Z. Noskowskiego 12, 61-704 Poznan, Poland; \\ ateubert@ibch.poznan.pl \\ * Correspondence: tkoczorowski@ump.edu.pl
}

check for updates

Citation: Koczorowski, T.; Szczolko, W.; Teubert, A.; Goslinski, T. Sulfanyl Porphyrazines with

Morpholinylethyl

Periphery-Synthesis,

Electrochemistry, and Photocatalytic

Studies after Deposition on

Titanium(IV) Oxide P25

Nanoparticles. Molecules 2021, 26,

2280. https://doi.org/10.3390/

molecules 26082280

Academic Editor: Ana Margarida

Gomes da Silva

Received: 29 March 2021

Accepted: 13 April 2021

Published: 15 April 2021

Publisher's Note: MDPI stays neutral with regard to jurisdictional claims in published maps and institutional affiliations.

Copyright: (c) 2021 by the authors. Licensee MDPI, Basel, Switzerland. This article is an open access article distributed under the terms and conditions of the Creative Commons Attribution (CC BY) license (https:// creativecommons.org/licenses/by/ $4.0 /)$.

\begin{abstract}
The syntheses, spectral UV-Vis, NMR, and electrochemical as well as photocatalytic properties of novel magnesium(II) and zinc(II) symmetrical sulfanyl porphyrazines with 2-(morpholin-4yl)ethylsulfanyl peripheral substituents are presented. Both porphyrazine derivatives were synthesized in cyclotetramerization reactions and subsequently embedded on the surface of commercially available P25 titanium(IV) oxide nanoparticles. The obtained macrocyclic compounds were broadly characterized by ESI MS spectrometry, 1D and 2D NMR techniques, UV-Vis spectroscopy, and subjected to electrochemical studies. Both hybrid materials, consisting of porphyrazine derivatives embedded on the titanium(IV) oxide nanoparticles' surface, were characterized in terms of particle size and distribution. Next, they were subjected to photocatalytic studies with 1,3-diphenylisobenzofuran, a known singlet oxygen quencher. The applicability of the obtained hybrid material consisting of titanium(IV) oxide P25 nanoparticles and magnesium(II) porphyrazine derivative was assessed in photocatalytic studies with selected active pharmaceutical ingredients, such as diclofenac sodium salt and ibuprofen.
\end{abstract}

Keywords: catalysis; electrochemistry; morpholine; porphyrazine; titanium(IV) oxide

\section{Introduction}

Porphyrazines (Pzs) are synthetic tetrapyrrole macrocyclic molecules, known as azaanalogues of porphyrins. Their physicochemical properties can be tuned by the exchange of the central metal cation or by peripheral substitution [1]. Substituted porphyrazines reveal high absorption in the UV-Vis region and good effectiveness for singlet oxygen generation. In addition, they are usually soluble in organic solvents [2-5]. Their unique physicochemical properties, including optical and electrochemical ones, make them useful in biosensing [6], photocatalysis [7], nonlinear optics [8], and biomedicine, where they can be considered as photosensitizers for photodynamic therapy [9]. Amino and sulfanyl porphyrazines can be obtained from a cyclotetramerization reaction starting from diaminomaleonitrile or dimercaptomaleonitrile disodium salt derivatives, respectively.

Porphyrazines peripherally substituted with sulfanyl moieties have been studied widely over the last twenty years. They are well-soluble in common organic solvents [10-12], and present interesting optical $[13,14]$ and electrochemical properties, and have therefore been applied as sensing materials in technology [15-21]. Other applications of sulfanyl Pzs concern photodynamic therapy (PDT) [22-24], wastewater treatment [25-27], and catalysis [28-31]. Symmetrical octa-substituted sulfanyl porphyrazines, unlike their unsymmetrical derivatives, usually present low singlet oxygen generation quantum yields, and therefore their biological activities are limited [32,33]. Recently, many symmetrical and 
unsymmetrical magnesium(II) and zinc(II) sulfanyl porphyrazines with bulky dendrimeric periphery were synthesized and evaluated in terms of their suitability for photodynamic therapy (PDT) [34-38]. In addition, some sulfanyl porphyrazines and phthalocyanines with morpholinyl moieties were studied as photosensitizers for PDT and photodynamic antimicrobial chemotherapy (PACT) and revealed promising potential [39-41].

Due to the presence of an expanded aromatic system in porphyrazines, they are often highly hydrophobic, and therefore less soluble or even insoluble in water. Thus, diverse methods, using specific carriers, have been employed to allow porphyrazines and related compounds to form stable suspensions in aqueous solutions. The carriers most widely applied in medicine and technology are liposomes [24,42,43], metal and metal oxide nanoparticles [44-46], and polymeric nanomaterials [47]. Among the metal oxide nanoparticles, one of the most interesting is titanium(IV) oxide nanoparticles $\left(\mathrm{TiO}_{2}\right)$, which have unique photochemical features. Uncoated $\mathrm{TiO}_{2}$ nanoparticles are photoactive only when irradiated with UV light. However, $\mathrm{TiO}_{2}$ nanocarriers coated with photoactive compounds, like porphyrinoid macrocycles, when irradiated with light of an appropriate energy, can absorb light and participate in energy transfer, and thus more effectively take part in photochemical reactions [48-50].

Herein, we present the synthesis, spectral UV-Vis, NMR, and electrochemical as well as photocatalytic properties of novel magnesium(II) and zinc(II) symmetrical sulfanyl porphyrazines with 2-(morpholin-4-yl)ethylsulfanyl peripheral substituents. The synthesized macrocyclic compounds were embedded on the surface of commercially available P25 titanium(IV) oxide nanoparticles. The obtained grafted hybrid material was subjected to photocatalytic studies with 1,3-diphenylisobenzofuran, a known singlet oxygen quencher, and with diclofenac sodium salt and ibuprofen as examples of active pharmaceutical ingredients.

\section{Results and Discussion}

\subsection{Synthesis and Physicochemical Characterization}

The synthetic pathway was based on the alkylation reaction of commercially available mercaptomaleonitrile disodium salt (1) with 4-(2-chloroethyl)morpholine hydrochloride (2) in dimethylformamide (DMF), and with potassium carbonate as a base, which led to compound $\mathbf{3}$ (Scheme 1) [20,51]. Next, the Linstead macrocyclization reaction of 3 with magnesium butanolate as a base in $n$-butanol led to novel symmetric sulfanyl magnesium(II) porphyrazine 4 [52]. Simultaneously, compound 3 was also used in the macrocyclization reaction with $\mathrm{Zn}(\mathrm{OAc})_{2}$ and 1,8-diazabicyclo[5.4.0]undec-7-ene (DBU) in n-pentanol to give zinc(II) porphyrazine 5 [53].<smiles>N#CC([Sn+])=C([Sn+])C#N</smiles>

1<smiles>ClCC[N+]1(CCl)CCOCC1</smiles>

2<smiles>N#CC(SCCN1CCOCC1)=C(C#N)SCCN1CCOCC1</smiles>
3

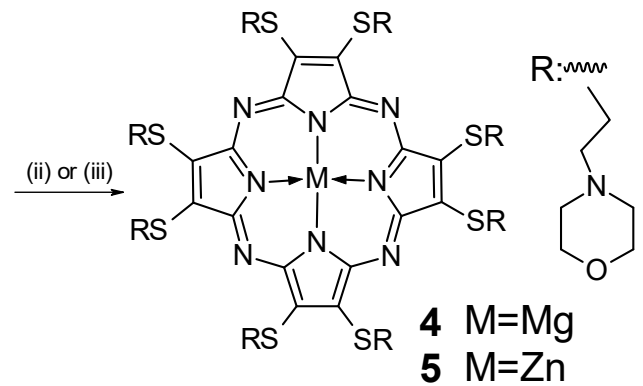

Scheme 1. Reagents and conditions: (i) $\mathrm{K}_{2} \mathrm{CO}_{3}, \mathrm{DMF}, 60^{\circ} \mathrm{C}, 24 \mathrm{~h}$; (ii) $\mathrm{Mg}(n \text {-BuO)})_{2}, n$-butanol, reflux, $24 \mathrm{~h}$; (iii) $\mathrm{Zn}(\mathrm{OAc})_{2}$, DBU, n-pentanol, reflux, 24 h; DBU-1,8-diazabicyclo[5.4.0]undec-7-ene, DMF-dimethylformamide.

All synthesized novel macrocyclic compounds were characterized using various analytical techniques, including high-resolution mass spectra (ESI), one- and two-dimensional NMR spectroscopy, and UV-Vis spectrophotometry. Notably, Pzs 4 and 5 have very low melting points at $113-116^{\circ} \mathrm{C}$ and $121-123^{\circ} \mathrm{C}$, respectively, which is relatively low compared with other sulfanyl and amino porphyrazines that melt over $300{ }^{\circ} \mathrm{C}[20,54]$. 
In the UV-Vis spectra of porphyrazines 4 and 5 in dichloromethane, two intensive bands were found: a Soret or B band in the range of 250-400 nm, and a Q band between 600 and $800 \mathrm{~nm}$ (Figure 1). Magnesium(II) Pz 4 revealed strong absorption Soret and Q bands with maxima at $375 \mathrm{~m}$ and $671 \mathrm{~nm}$, whereas zinc(II) Pz 5 maxima appeared at 373 and $668 \mathrm{~nm}$, respectively. The only difference between the UV-Vis spectra of 4 and 5 was noted in the region between 450 and $550 \mathrm{~nm}$, where, for Pz 4, only a weak absorption maximum at $497 \mathrm{~nm}$ appeared. A similar effect was noted before for sulfanyl porphyrazines with peripheral phthalimide motifs [38].

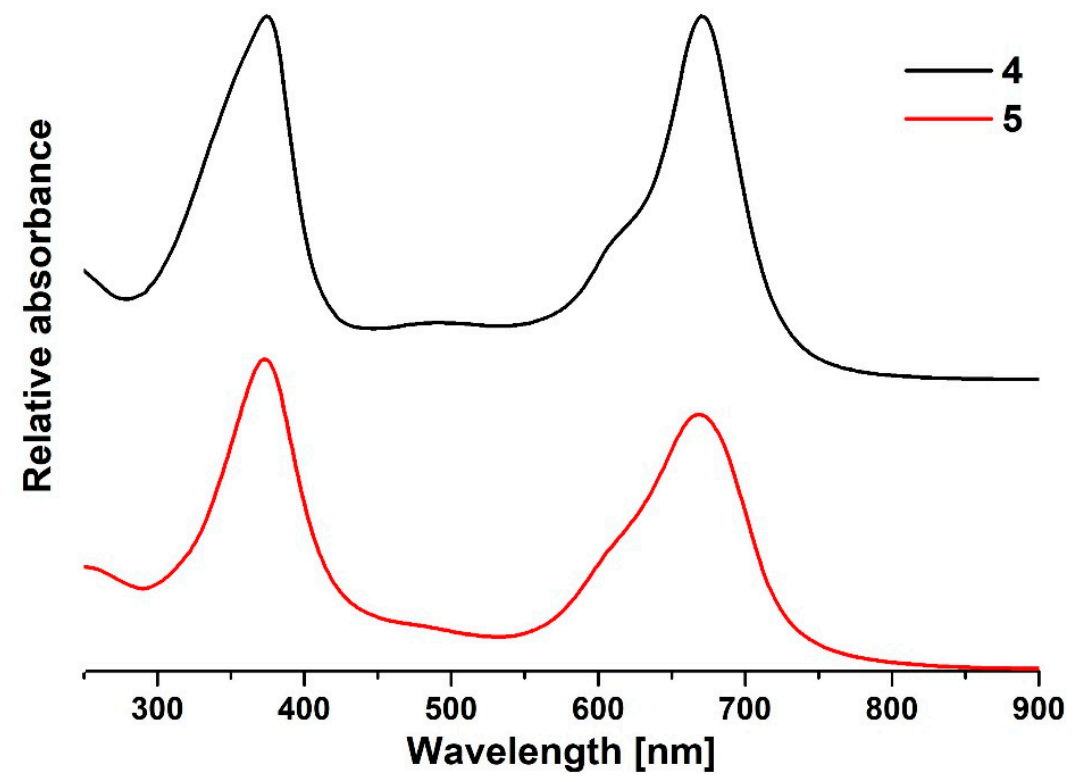

Figure 1. The UV-Vis spectrum of Pz 4 (black line) and Pz 5 (red line) in dichloromethane.

In the NMR spectra of porphyrazines 4 and 5 , which were recorded in pyridine- $d_{5}$, four distinguishable signals in the aliphatic region were noted in the ${ }^{1} \mathrm{H} N \mathrm{NM}$, whereas there were six signals in the ${ }^{13} \mathrm{C}$ NMR (four aliphatic and two aromatic, originating from pyrrolyl rings of macrocycle, see Supplementary Materials). The two-dimensional technique ${ }^{1} \mathrm{H}-{ }^{1} \mathrm{H}$ COSY NMR was used to assist allocation and analysis of protons within ethylsulfanyl and morpholinyl substituents. Signal shift analyses performed for Pz 4 and Pz 5 indicated similarities for two morpholinyl proton signals and one of two methylene signals within the ethylene linker. A slight difference in the shifts of signals was noted for another methylene group within the ethylene linker. These methylene protons appeared as a singlet at $4.64 \mathrm{ppm}$ for $\mathrm{Pz}$ 4, and as a multiplet in the range of 3.81-3.89 ppm for Pz 5. In addition, in the ${ }^{1} \mathrm{H}$ NMR spectra of $\mathrm{Pz} 4$ and 5, the proton signals were generally up-field shifted in comparison with those in the structure of symmetrical magnesium(II) phthalocyanine with eight 2-(morpholin-4-yl)ethoxy substituents [39]. This finding could be explained by a higher electronegativity of oxygen atoms than sulfur present in the peripheries of both groups of macrocycles.

\subsection{Electrochemistry}

The electrochemical study was performed to assess the electrochemical properties of the obtained porphyrazines, aiming to propose their prospective potential applicabilities. The cyclic (CV) and differential pulse (DPV) voltammetry measurements were conducted in organic solvent (dichloromethane), with the addition of supporting electrolyte: $0.1 \mathrm{M}$ tetrabutylammonium perchlorate. The classic three-electrode system was employed with the glassy carbon working electrode. Due to the use of Ag wire as a pseudo-reference electrode, the ferrocene was added as an internal standard, and all results were adjusted to the ferrocene/ferrocenium peak potential. In the CV experiments, the scan potential range 
was set between 50 and $250 \mathrm{mV} / \mathrm{s}$. The obtained results are presented in Figures 2 and 3 and Table 1.

In the voltammograms recorded for both porphyrazines 4 and 5 , four redox peak potentials were noted. Almost all redox peaks observed in the $\mathrm{CV}$ voltammograms are irreversible due to the aggregation-disaggregation behavior of porphyrazines in dichloromethane; thus, redox pairs can be observed only in the DPV measurements. A similar phenomenon was previously observed for iron(II) porphyrazine bearing identical periphery to both herein studied Pzs [20]. However, the oxidation peaks (IV) at $0.62 \mathrm{~V}$ for Pz 4 and $0.53 \mathrm{~V}$ for Pz 5 were noted in the DPV voltammogram only when the applied potential was increasing over time from -2.0 to $0.7 \mathrm{~V}$. Conversely, when the applied potential was decreasing over time, oxidation peaks were not observed (Figures 2 and 3). The oxidation peak currents were at least five times higher than the highest reduction peak (I) in the case of both porphyrazines (Figures 2 and 3). Such a high oxidation peak current could also be a result of an aggregation phenomenon, which was previously observed for other sulfanyl porphyrazines [15]. Notably, the peak potentials of zinc(II) porphyrazine 5 shifted to more negative potentials in comparison with magnesium(II) complex 4 (Table 1), which is the result of different metal cations present inside their cores [55].
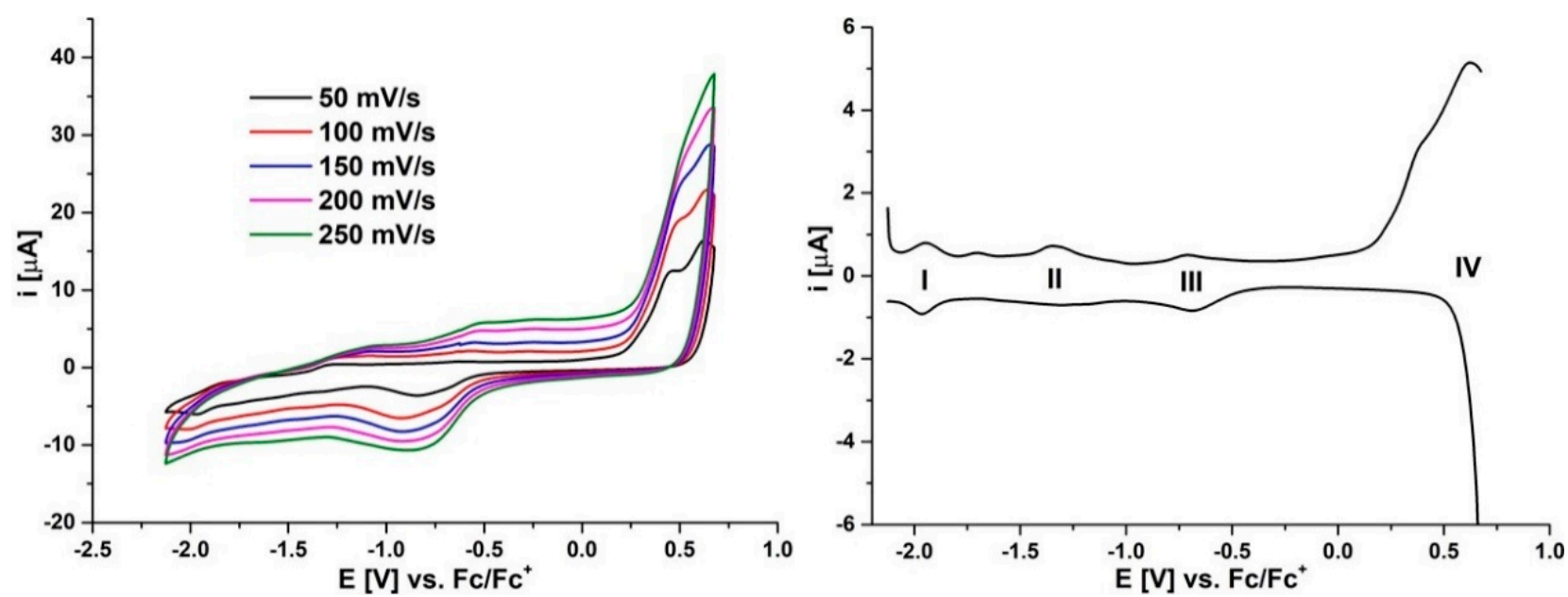

Figure 2. The cyclic and differential pulse voltammograms of porphyrazine 4 in 0.1 M TBAP/DCM. The DPV parameters: modulation amplitude $20 \mathrm{mV}$ and step rate $5 \mathrm{mV} \cdot \mathrm{s}^{-1}$.
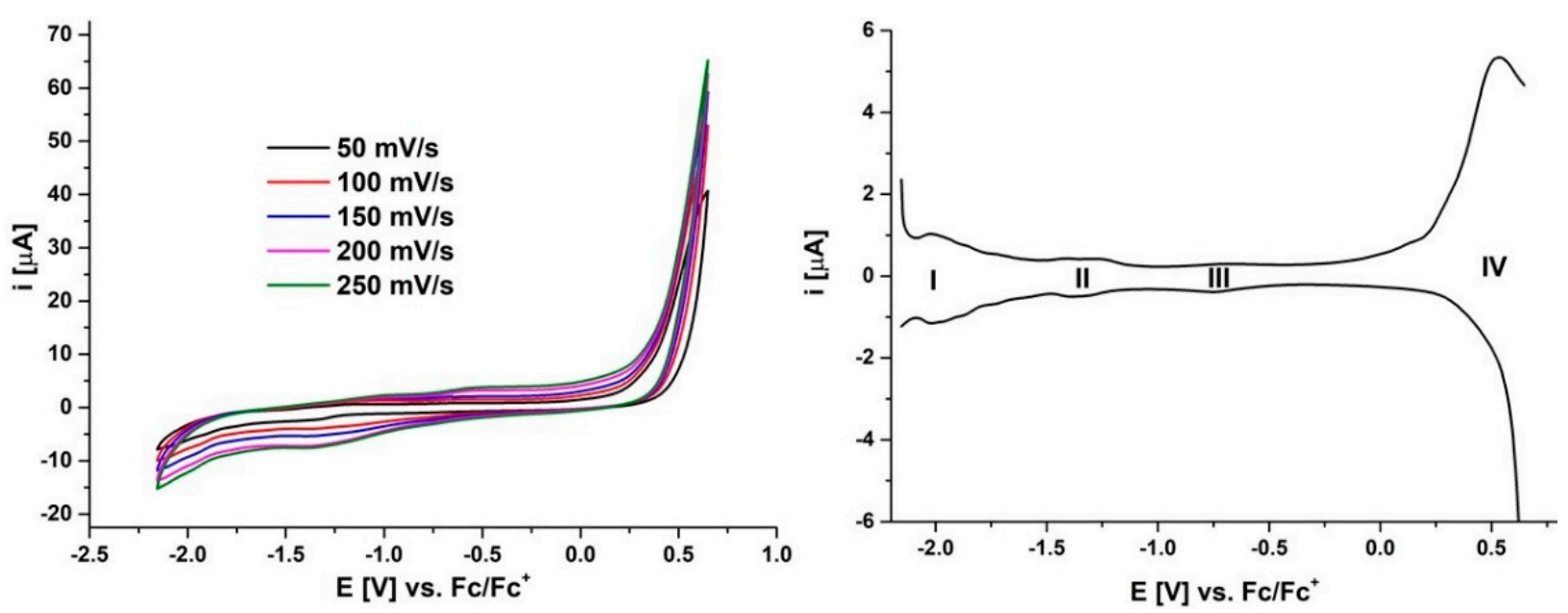

Figure 3. The cyclic and differential pulse voltammograms of porphyrazine 5 in $0.1 \mathrm{M}$ TBAP/DCM. The DPV parameters: modulation amplitude $20 \mathrm{mV}$ and step rate $5 \mathrm{mV} \cdot \mathrm{s}^{-1}$. 
Measurements performed for amino porphyrazines in dichloromethane indicated that the first oxidation peak appears below $0 \mathrm{~V}$ vs. $\mathrm{Fc} / \mathrm{Fc}^{+}$[56,57]. A different situation was observed when alkyl- or phenylsulfanyl substituents were present in the macrocyclic periphery. Then, peaks shifted toward positive values due to a strong electron-withdrawing effect $[55,58]$. The oxidation peak potentials (IV) of Pzs 4 and 5 comply with this rule.

Table 1. The electrochemical data of porphyrazines 4 and 5.

\begin{tabular}{cccccc}
\hline $\mathbf{P z}$ & & $\begin{array}{c}\mathbf{M P z}^{(-2) /} \\
\mathbf{M P z} \\
\mathbf{I}\end{array}$ & $\begin{array}{c}\mathbf{M P z} \\
\mathbf{M P z} \\
\mathbf{I I}\end{array}$ & $\begin{array}{c}\mathbf{M P z}^{(-2)} / \\
\mathbf{M P z}^{(-1)} \\
\mathbf{I I I}\end{array}$ & $\begin{array}{c}\mathbf{M P z}^{(\mathbf{0}) /} \\
\mathbf{M P z}^{(+1)} \\
\mathbf{I V}\end{array}$ \\
\hline \multirow{2}{*}{$\mathbf{4}$} & $\begin{array}{r}\mathrm{E}_{1 / 2}[\mathrm{~V}] \\
\text { vs. Fc/Fc }\end{array}$ & -1.95 & -1.33 & -0.70 & 0.62 \\
\hline \multirow{5}{*}{$\mathbf{5}$} & $\begin{array}{r}\mathrm{E}_{1 / 2}[\mathrm{~V}] \\
\text { vs. Fc } / \mathrm{Fc}^{+}\end{array}$ & -2.02 & -1.34 & -0.74 & 0.53 \\
\hline
\end{tabular}

In order to calculate the HOMO-LUMO energy levels in compounds such as porphyrinoid macrocycles, electrochemical measurements were used. The electrochemical energy gap $\left(E_{\text {gap el }}\right)$ was calculated by determining the onset potentials of first oxidation and first reduction processes originating from the porphyrazine ring with the use of the following equations:

$$
\begin{gathered}
E_{\mathrm{HOMO}}=-\left(V_{\text {onset ox }}-V_{\mathrm{FOC}}+4.8\right) \mathrm{eV}, \\
E_{\mathrm{LUMO}}=-\left(V_{\text {onset red }}-V_{\mathrm{FOC}}+4.8\right) \mathrm{eV}, \\
E_{\text {gap el }}=\left(E_{\mathrm{LUMO}}-E_{\mathrm{HOMO}}\right) \mathrm{eV}
\end{gathered}
$$

In the above equations, $V_{\mathrm{FOC}}$ stands for the ferrocene half-wave potential, $V_{\text {onset ox }}$ is assigned as the Pz oxidation onset, and $V_{\text {onset red }}$ represents the Pz reduction onset. For all these values $(\mathrm{eV})$, the calculations of the first oxidation and the first reduction were adjusted to the ferrocene's energy level at $-4.8 \mathrm{eV}$. The value of $4.8 \mathrm{eV}$ refers to a standard electrode potential for normal hydrogen electrode (NHE) at $-4.6 \mathrm{eV}$ on the zero vacuum level scale, and a value of $0.2 \mathrm{eV}$ versus NHE for the potential of ferrocene standard $[59,60]$. The calculated electrochemical energy gap was slightly higher for magnesium(II) porphyrazine 4 than for zinc(II) complex 5 (Figure 4 and Table 2).

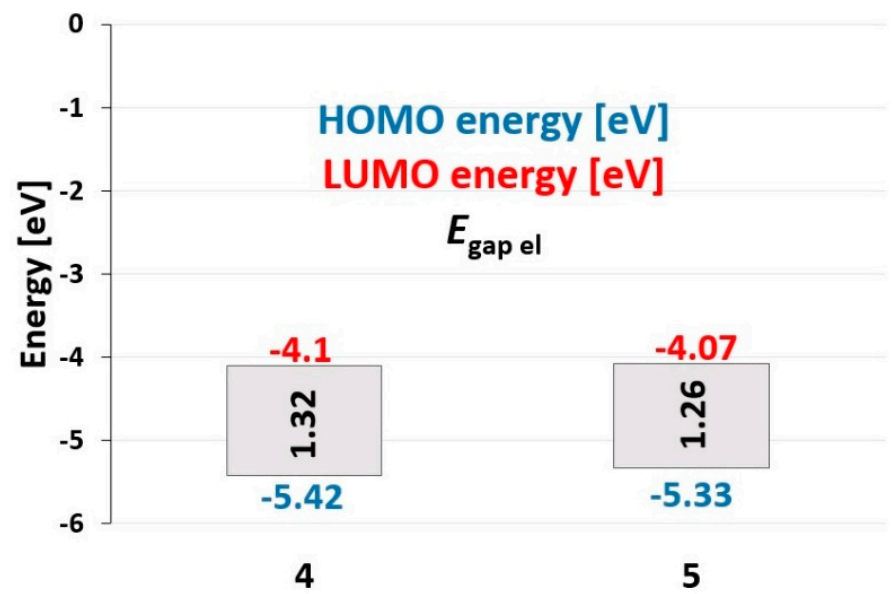

Figure 4. The HOMO-LUMO energy levels estimated for electrochemical data for porphyrazines 4 and 5.

At the same time as the previous calculations, we calculated the optical band gaps ( $E_{\text {gap opt }}$ ) based on the UV-Vis spectra $\mathrm{Q}$ band onsets, according to the equation $\mathrm{E}=$ $h c / \lambda_{\text {onset }}[61]$. Both electrochemical and optical energy gaps, which we obtained, were subsequently compared and are presented in Table 2 . The optical band gaps ( $E_{\text {gap opt }}$ ) 
for porphyrazines 4 and 5 were found to be in agreement with those obtained from electrochemical measurements within approx. $0.2 \mathrm{eV}$.

Table 2. The optical and electrochemical HOMO-LUMO band gaps for porphyrazines 4 and 5 .

\begin{tabular}{|c|c|c|c|c|c|}
\hline & \multicolumn{2}{|c|}{$\lambda_{\max }[\mathrm{nm}]$} & \multirow{2}{*}{$\lambda_{\text {onset }}[\mathrm{nm}]$} & \multirow{2}{*}{$\begin{array}{c}\text { Optical Band Gap } \\
E_{\text {gap opt }}[\mathrm{eV}]\end{array}$} & \multirow{2}{*}{$\begin{array}{c}\text { Electrochemical Band } \\
\text { Gap } E_{\text {gap el }}[\mathrm{eV}]\end{array}$} \\
\hline & Soret & Q Band & & & \\
\hline 4 & 375 & 671 & 820 & 1.51 & 1.32 \\
\hline 5 & 373 & 668 & 850 & 1.46 & 1.26 \\
\hline
\end{tabular}

\section{3. $\mathrm{TiO}_{2}$ Deposition and Characterization}

Titanium(IV) oxide $\left(\mathrm{TiO}_{2}\right)$ nanoparticles have often been utilized in diverse studies as carriers for photosensitizers [62,63]. Among many titanium(IV) oxide types, the commercially available P25, consisting of a mixture of crystal phases of anatase and rutile, is the most popular. Herein, the hybrid materials, type Pz@P25, were prepared by depositing porphyrazine 4 or 5 on the surface of $\mathrm{TiO}_{2}$ nanoparticles. The solutions of macrocycles were added to titania suspension, sonicated, and mixed for 72 h, yielding 4@P25 and 5@P25, respectively. The resulting hybrid materials contained $5 \%(w / w)$ of the macrocycle. The sizes and the dispersities of the obtained nanomaterials were subjected to the detailed analyses using a NanoSight LM10 instrument (sCMOS camera, $405 \mathrm{~nm}$ laser), equipped with a nanoparticle tracking analysis system. The diameters of the obtained hybrid materials were assessed and compared with the pure $\mathrm{TiO}_{2}$ nanoparticles. The results are presented in Table 3.

Table 3. The particle size distribution of P25, 4@P25, and 5@P25.

\begin{tabular}{ccc}
\hline Material & Measured Particle Size (nm) & Polydispersity Index $^{\mathbf{a}^{\mathbf{2}}}$ \\
\hline P25 & $74.8 \pm 7.7$ & 0.17 \\
\hline $\mathbf{4} @ \mathrm{P} 25$ & $327.4 \pm 15.5$ & 0.13 \\
\hline $5 @ \mathrm{P} 25$ & $322.5 \pm 28.2$ & 0.15 \\
\hline
\end{tabular}

${ }^{a}$ Calculated according to the formula PDI $=(\mathrm{SD} / \text { mean diameter })^{2}[64]$.

Considering the measured particle size values, strong agglomeration of the hybrid nanoparticles was observed. The mean particle sizes of the 4@P25 and 5@P25 were four times higher than the unmodified P25 $(74.8 \pm 7.7 \mathrm{~nm})$. This could suggest that the deposition of the macrocycles strongly influences the titanium(IV) oxide nanoparticles. In addition, in both cases, the calculated polydispersity indices were below 0.2 , which indicated that the distributions of nanoparticles within the studied hybrid materials are monodisperse. It also seems that the presence of sulfanyl porphyrazines on the surface of P25 nanoparticles hampers the electrostatic interactions between Pz@P25 nanoparticles and allows obtaining Pz@P25 of specific diameters.

\subsection{Photocatalysis}

All hybrid materials were assessed for their photocatalytic oxidation abilities. These properties were studied with the use of a known singlet oxygen quencher, 1,3diphenylisobenzofurane (DPBF), according to previously presented procedures [20,65]. In the UV-Vis spectrum, the decrease in the DPBF absorption band at $413 \mathrm{~nm}$ over a period of time results from the transformation of DPBF towards the new product, which is 1,2-dibenzoylbenzene (Scheme 2).

Measurements were performed in DMF at ambient temperature, and with the use of red-light LED lamps $(665 \mathrm{~nm})$. The intensity of light was adjusted to $10 \mathrm{~mW} / \mathrm{cm}^{2}$. The irradiations were conducted in a $10 \mathrm{~mm}$ quartz cuvette equipped with a magnetic stirrer. The results of photocatalytic reactions were evaluated with the use of UV-Vis spectrophotometry. 
<smiles>O=C(c1ccccc1)c1ccc(Cl)cc1C(=O)c1ccccc1</smiles>

Scheme 2. The oxidation of 1,3-diphenylisobenzofurane to 1,2-dibenzoylbenzene.

The photocatalytic oxidations of DPBF were performed using three types of materials: 4@P25, 5@P25, and unmodified P25. Their catalytic activity was assessed by recording the UV-Vis scans within the range of $250-800 \mathrm{~nm}$ for $8 \mathrm{~min}$, and every $2 \mathrm{~min}$. The $4 @ \mathrm{P} 25$ hybrid material containing magnesium(II) sulfanyl porphyrazine deposited on the surface of $\mathrm{TiO}_{2}$ nanoparticles revealed the highest photocatalytic activity. Moderate activity was noted for 5@P25 and the lowest activity for the unmodified P25 (Figure 5). In the case of $5 @ \mathrm{P} 25$ nanoparticles, the linear plots of DPBF absorbance were decreasing with time, which indicates that the photooxidation process follows the first-order kinetics (Figure 5D). In the parallel study, the $\mathrm{R}^{2}$ value measured for $4 @ \mathrm{P} 25$ hybrid material and P25 nanoparticles slightly deviated from unity.
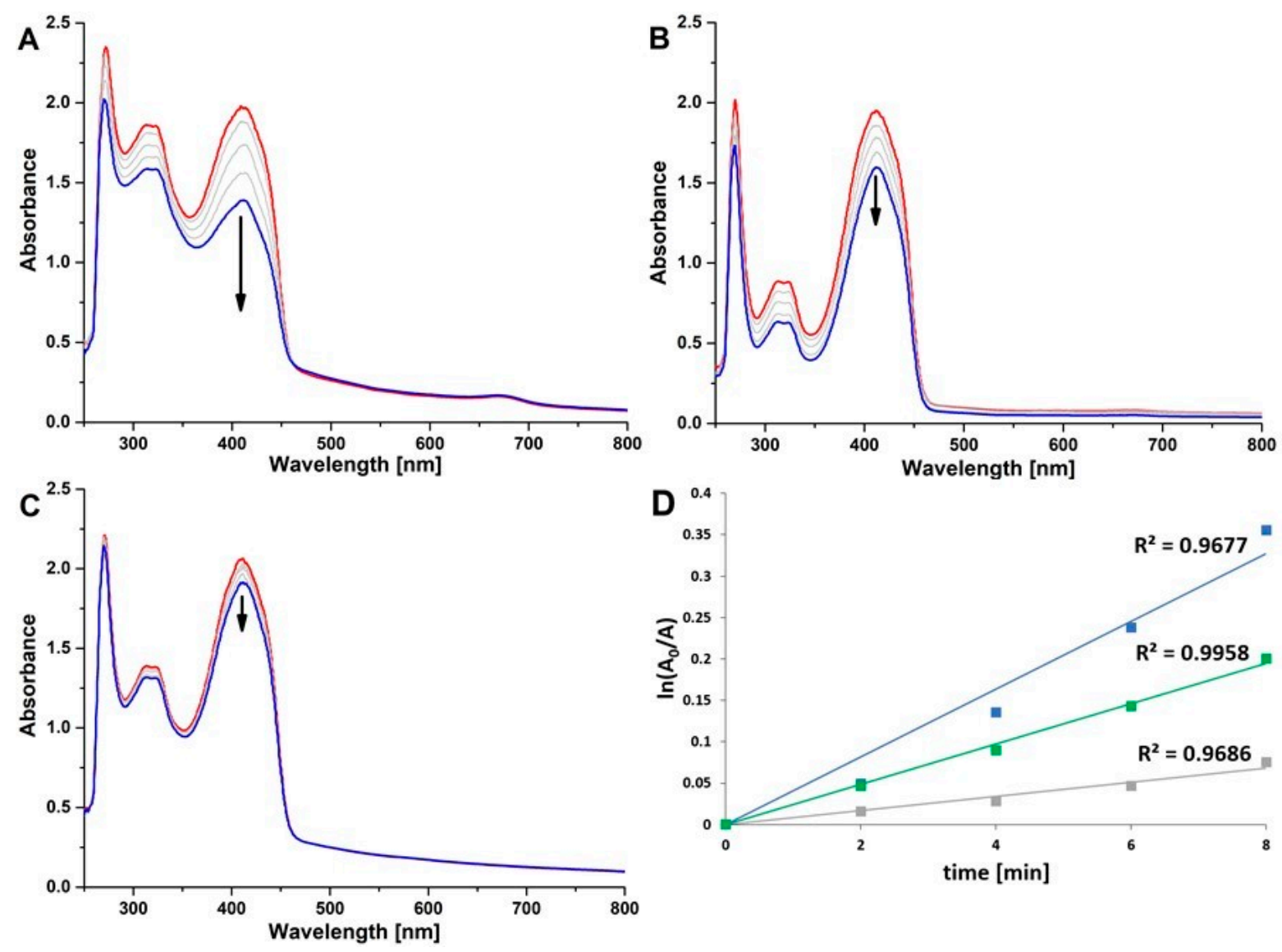

Figure 5. The UV-Vis spectra for the oxidation of DPBF in dimethylformamide in the presence of 4@P25 (A), $5 @ P 25$ (B), and P25 (C) as catalysts over a period of time. (D) the plots of DPBF absorbance in time in the presence of 4@P25 (blue), $5 @$ P25 (green), and P25 (grey); DPBF-1,3-diphenylisobenzofurane.

The results obtained in the photocatalytic oxidation study with DPBF indicated the 4@P25 hybrid material as a candidate for further photocatalytic study with selected active pharmaceutical ingredients (APIs): diclofenac sodium salt and ibuprofen. Both APIs are 
common non-steroidal anti-inflammatory drugs, and therefore constitute an important component of drug-related pollutants in water. What is essential is that the UV-Vis method can be employed for the photodegradation study of both APIs. The photodegradation study was performed in the same conditions as previously established for the photooxidation of DPBF. The results are presented in Figure 6. In the UV-Vis spectra, decreases in both APIs absorbances over a period of time were observed, which indicates the photodegradation of the studied compounds. For this reason, the obtained hybrid material 4@P25 can be considered an efficient heterogenic catalyst for further photooxidation studies of diverse organic compounds.
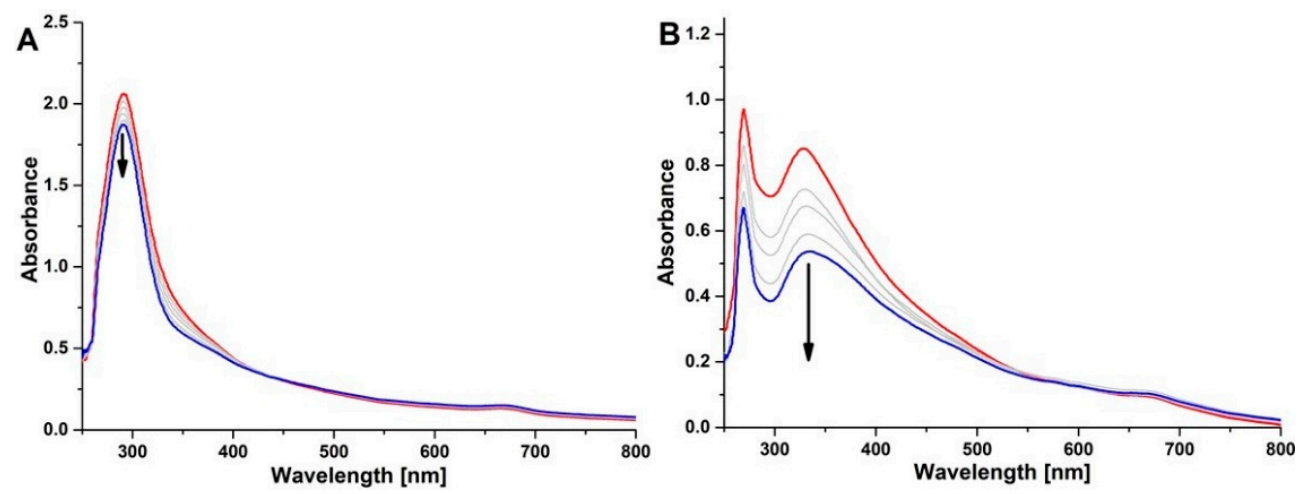

Figure 6. The UV-Vis spectra of photooxidation of diclofenac sodium salt (A) and ibuprofen (B) in dimethylformamide with $4 @ \mathrm{P} 25$ as a catalyst over a period of time.

\section{Materials and Methods}

\subsection{Materials and Instruments}

All the reactions described in this paper were conducted under argon. Before attempting the reaction, the glassware was oven-dried (at $140{ }^{\circ} \mathrm{C}$ ). All solvents were rotary evaporated under vacuum at or below $40^{\circ} \mathrm{C}$. All reaction temperatures reported in the experimental section refer to the external bath temperatures. The reactions were performed on a Heidolph MR Hei-Tec, equipped with Radleys Heat-On heating mantle. All solvents and reagents were obtained from commercial suppliers (Merck, Darmstadt, Germany; TCI, Zwijndrecht, Belgium, and Fluorochem, Hadfield, UK), and used without any further purification, unless otherwise stated. Melting points were measured with the use of a Stuart Bibby apparatus (Triad Scientific, Staffordshire, UK) and are uncorrected. Flash column chromatography was performed on a Merck neutral aluminum oxide gel, whereas thinlayer chromatography (TLC) was performed on aluminum oxide F254 plates (Merck) and visualized with a UV lamp $\left(\lambda_{\max } 254\right.$ or $\left.365 \mathrm{~nm}\right)$. UV-Vis spectra were recorded with the use of an Ocean Optics USB 2000+ spectrometer (Ocean Opitics Inc., Largo, FL, USA). ${ }^{1} \mathrm{H}$ NMR and ${ }^{13} \mathrm{C}$ NMR spectra were recorded using Bruker Avance 400 and 500 (Bruker, Karlsruhe, Germany) spectrometers. Chemical shifts $(\delta)$ are specified in parts per million (ppm) and are referenced against a residual solvent peak (pyridine- $d_{5}$ ), whereas coupling constants $(J)$ are calculated in Hertz $(\mathrm{Hz})$. The abbreviations $s, t$, and $m$ refer to singlet, triplet, and multiplet, respectively. Mass spectra (ESI MS) were performed in the Wielkopolska Centre of Advanced Technologies, Adam Mickiewicz University in Poznan, Poland.

\subsection{Synthesis}

2,3-Bis[2-(morpholin-4-ylo)ethylsulfanyl]-(2Z)-butene-1,4-dinitrile (3) is a known compound synthesized and characterized earlier in our group [20]: dimercaptomaleonitrile disodium salt (558 mg; $3.0 \mathrm{mmol}$ ) (1), 4-(2-chloroethyl)morpholine hydrochloride (1.396 g; $7.5 \mathrm{mmol})(2)$ and $\mathrm{K}_{2} \mathrm{CO}_{3}(4.140 \mathrm{~g} ; 30.0 \mathrm{mmol})$ were mixed in DMF $(30 \mathrm{~mL})$ at $60{ }^{\circ} \mathrm{C}$ for $24 \mathrm{~h}$ under argon. Next, the reaction mixture was cooled to room temperature and filtered through Celite, then the filtrate was evaporated with toluene to a dry solid residue. Crude 
solid was subjected to a flash column chromatography with $\mathrm{Al}_{2} \mathrm{O}_{3}\left(\mathrm{DCM}: \mathrm{CH}_{3} \mathrm{OH} ; 50: 1\right)$ to give 3 as yellow crystals ( $810 \mathrm{mg}$; $71 \%$ yield).

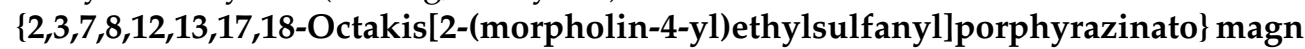
esium(II) (4): magnesium turnings (45 $\mathrm{mg} ; 1.88 \mathrm{mmol}$ ) and iodide (1 crystal) were suspended in $n$-butanol $(15 \mathrm{~mL})$ and refluxed for $6 \mathrm{~h}$ in an inert atmosphere. After the reaction mixture was cooled to room temperature, compound 3 (692 $\mathrm{mg} ; 1.88 \mathrm{mmol}$ ) was added and the mixture was refluxed for $18 \mathrm{~h}$. Next the mixture was filtrated through Celite and the solvents were evaporated with toluene to a dry solid. Crude product was purified by column chromatography on $\mathrm{Al}_{2} \mathrm{O}_{3}$ (DCM:MeOH, 50:1) to give porphyrazine 4 (110 mg; $16 \%$ yield) as a green-blue solid: $\mathrm{mp} 113-116{ }^{\circ} \mathrm{C} ; \mathrm{R}_{f}\left(\mathrm{DCM}: \mathrm{MeOH}: \mathrm{N}\left(\mathrm{C}_{2} \mathrm{H}_{5}\right)_{3}, 10: 1: 0.1\right)$ 0.42. UV-Vis (DCM): $\lambda_{\max }, \mathrm{nm}(\log \varepsilon) 375$ (4.68), 497 (3.91), $671(4.71) .{ }^{1} \mathrm{H}$ NMR $\left(400 \mathrm{MHz}\right.$; pyridine- $\left.d_{5}\right)$ : $\delta H$, ppm $2.60\left(s, 32 \mathrm{H}\right.$, morph- $\left.\mathrm{CH}_{2}\right), 3.11\left(\mathrm{~s}, 16 \mathrm{H}, \mathrm{CH}_{2}\right), 3.67\left(\mathrm{~s}, 32 \mathrm{H}\right.$, morph- $\left.\mathrm{CH}_{2}\right), 4.64(t$, $\left.{ }^{3} J=10.0 \mathrm{~Hz}, 16 \mathrm{H}, \mathrm{CH}_{2}\right) .{ }^{13} \mathrm{C}$ NMR $\left(100 \mathrm{MHz}\right.$; pyridine- $\left.d_{5}\right): \delta \mathrm{C}, \mathrm{ppm} 33.5 ; 54.5 ; 60.0 ; 67.5$; 141.9; 158.4. HRMS ESI (pos): calc. for $\mathrm{C}_{64} \mathrm{H}_{97} \mathrm{~N}_{16} \mathrm{O}_{8} \mathrm{~S}_{8} \mathrm{Mg} \mathrm{m} / z 1497.5291[\mathrm{M}+\mathrm{H}]^{+}$; found $m / z 1497.5340[\mathrm{M}+\mathrm{H}]^{+}$.

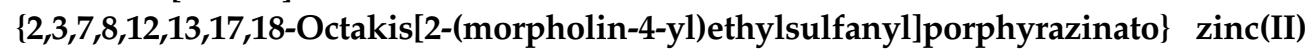
(5): dimercaptomaleonitrile 3 (700 mg; $1.9 \mathrm{mmol}), \mathrm{Zn}(\mathrm{OAc})_{2}(175 \mathrm{mg}, 0.95 \mathrm{mmol})$ and DBU $(142 \mu \mathrm{L}, 0.95 \mathrm{mmol})$ in $n$-pentanol $(4 \mathrm{~mL})$ were refluxed in an inert atmosphere for $18 \mathrm{~h}$. Next, the reaction mixture was filtrated through Celite and the filtrate was evaporated with toluene to dryness. Crude solid was purified by column chromatography with $\mathrm{Al}_{2} \mathrm{O}_{3}$ (DCM:MeOH; $50: 1 \rightarrow 10: 1)$ to give porphyrazine 5 (90 mg; $12 \%$ ) as a dark green solid: $\mathrm{mp}$ 121-123 ${ }^{\circ} \mathrm{C} ; \mathrm{R}_{f}$ (DCM:MeOH:N($\left.\left(\mathrm{C}_{2} \mathrm{H}_{5}\right)_{3}, 10: 1: 0.1\right)$ 0.57. UV-Vis (DCM): $\lambda_{\max }, \mathrm{nm}(\log \varepsilon) 373$ (4.79); 668 (4.71). ${ }^{1} \mathrm{H}$ NMR (500 MHz; pyridine- $\left.d_{5}\right)$ : $\delta H, \mathrm{ppm} 2.54-2.63(m, 32 \mathrm{H}$, morph$\left.\mathrm{CH}_{2}\right), 3.09\left(\mathrm{~s}, 16 \mathrm{H}, \mathrm{CH}_{2}\right), 3.63-3.69\left(m, 32 \mathrm{H}\right.$, morph- $\left.\mathrm{CH}_{2}\right), 3.81-3.89\left(m, 16 \mathrm{H}, \mathrm{CH}_{2}\right) .{ }^{13} \mathrm{C}$ NMR (125 MHz; pyridine- $\left.d_{5}\right): \delta C$, ppm 33.34; 54.37; 59.88; 67.38; 141.92; 157.34. HRMS ESI (pos): calc. for $\mathrm{C}_{64} \mathrm{H}_{97} \mathrm{~N}_{16} \mathrm{O}_{8} \mathrm{~S}_{8} \mathrm{Zn} m / z 1539.4721[\mathrm{M}+\mathrm{H}]^{+}$; found $\mathrm{m} / z 1539.4756[\mathrm{M}+\mathrm{H}]^{+}$.

\subsection{Electrochemical Studies}

The electrochemical studies were performed with a Metrohm Autolab PGSTAT128N potentiostat (Metrohm, Herisau, Switzerland). The data acquisition and storage were driven by Metrohm Nova 2.1.4 software (Metrohm). The measurements were obtained with the use of a glassy carbon (GC) working electrode (area $=0.071 \mathrm{~cm}^{2}$ ), Ag wire (pseudoreference electrode), and a platinum wire (counter electrode). Before each procedure, the GC electrode was polished with aqueous $50 \mathrm{~nm} \mathrm{Al}_{2} \mathrm{O}_{3}$ slurry (purchased from SigmaAldrich) using a polishing cloth and was subsequently washed in an ultrasonic bath with deionized water for $10 \mathrm{~min}$ to remove inorganic impurities. Ferrocene/ferrocenium couple $\left(\mathrm{Fc} / \mathrm{Fc}^{+}\right)$was applied as an internal standard. The solvent (dichloromethane) containing a supporting electrolyte $(0.1 \mathrm{M}$ tetrabutylammonium perchlorate (TBAP)) in a glass cell (volume $10 \mathrm{~mL}$ ) was deoxygenated by purging nitrogen gas for $10 \mathrm{~min}$ prior to each experiment. All electrochemical experiments were carried out at $22^{\circ} \mathrm{C}$. The solvent and reagent were purchased from Sigma-Aldrich Chemie $\mathrm{GmbH}$, Steinheim, Germany.

\subsection{Deposition of Porphyrazines on $\mathrm{TiO}_{2} P 25$ Nanoparticles}

Studied porphyrazines were deposited on P25 Aeroxide ${ }^{\circledR \circledast}$ titanium(IV) oxide $\left(\mathrm{TiO}_{2}\right)$ nanoparticles using the chemical deposition method [50]. In general, porphyrazine 4 or 5 in the amount of $5 \mathrm{mg}$ was added to a dispersion of $100 \mathrm{mg}$ P25 nanoparticles (sized approx. $21 \mathrm{~nm}$ ) in $20 \mathrm{~mL}$ of dichloromethane:methanol mixture $(1: 1, v / v)$. After the reaction mixture had been stirred for $72 \mathrm{~h}$, the solvents were evaporated on a rotary evaporator. Next, the obtained hybrid material was air dried for $24 \mathrm{~h}$. The ratio of the macrocycle to the $\mathrm{P} 25 \mathrm{TiO}_{2}$ was 1:20 $(w / w)$.

The hybrid materials were subjected to nanoparticle size measurements using a Malvern Panalytical NanoSight LM10 instrument (Malvern, UK), equipped with sCMOS camera, and $405 \mathrm{~nm}$ laser. The data acquisition and storage were provided by Nanoparticle Tracking Analysis (NTA) 3.2 Dev Build 3.2.16 software (Malvern, UK). Throughout, the 
nanoparticles' dispersions were diluted with water $(1 \mathrm{mg}$ in $1 \mathrm{~mL})$ to obtain the operating range of nanoparticle concentration. The measurements were performed at $25.0 \pm 0.1^{\circ} \mathrm{C}$, and at the syringe pump infusion rate set to $100 \mu \mathrm{L} / \mathrm{min}$.

\subsection{Photocatalytic Studies}

The photocatalytic studies were performed using a red-light LED lamp (EcoEnergy, Gdańsk, Poland) at wavelength $665 \mathrm{~nm}$, and a power adjusted to $10 \mathrm{~mW} / \mathrm{cm}^{2}$ with the use of an Optel radiometer. The measurements were conducted in a $10 \mathrm{~mm}$ quartz cuvette in $N, N^{\prime}$-dimethylformamide (DMF). In the experiments with a reference standard 1,3-diphenylisobenzofurane (DPBF), $1 \mathrm{~mL}$ of $0.1 \mathrm{mM}$ DPBF solution in DMF was mixed with $1 \mathrm{~mL}$ of $\mathrm{TiO}_{2}$ dispersion in DMF $(0.1 \mathrm{mg} / \mathrm{mL})$. In the experiments with active pharmaceutical ingredients (diclofenac sodium salt and ibuprofen), DPBF was replaced by $1 \mathrm{~mL}$ of $0.3 \mathrm{mM}$ diclofenac sodium salt solution in DMF or $1 \mathrm{~mL}$ of $1.5 \mathrm{mM}$ ibuprofen solution in DMF. The irradiations of mixtures were performed with an LED lamp within 8 min. The UV-Vis spectra were recorded every $2 \mathrm{~min}$ on an Ocean Optics USB 2000+ spectrometer (Ocean Optics Inc., Largo, FL, USA).

\section{Conclusions}

Two novel sulfanyl magnesium(II) and zinc(II) porphyrazines with morpholinylethyl periphery were synthesized in the cyclotetramerization reaction using a dimercaptomaleonitrile derivative. The obtained macrocyclic compounds were broadly characterized by ESI MS spectrometry, 1D and 2D NMR techniques, and UV-Vis spectroscopy. Both porphyrazines were subjected to electrochemical studies. Subsequently, the obtained porphyrazines were embedded on titanium(IV) oxide nanoparticles' surface and characterized in terms of particle size and distribution. The obtained hybrid materials' applicability was assessed in photocatalytic studies with a singlet oxygen quencher (DPBF) and selected drug active pharmaceutical ingredients (diclofenac sodium salt and ibuprofen). In the UV-Vis and NMR studies, the characteristic features of porphyrazines were confirmed. The electrochemical studies revealed four irreversible redox processes for both porphyrazines. In addition, the calculated electrochemical band gap values were found to be in agreement with the optical ones. Interestingly, the obtained hybrid materials presented four times higher particle sizes compared with unmodified titanium(IV) oxide P25 nanoparticles and were monodispersive. The $4 @ \mathrm{P} 25$ material was found to be the most active in comparative photocatalytic tests with 1,3-diphenylisobenzofurane, and it was therefore used in the photooxidation studies of diclofenac sodium salt and ibuprofen. The 4@P25 material revealed good photocatalytic potential. For this reason, it can be considered in future photocatalytic experiments with various organic compounds and active pharmaceutical ingredients as a potential hybrid material for the photodegradation of various organic pollutants.

Supplementary Materials: The following are available online: Figure S1. ${ }^{1} \mathrm{H}$ NMR spectrum of 4 in pyridine- $d_{5}$. \# indicates solvent residual peaks. Figure S2. ${ }^{13} \mathrm{C}$ NMR spectrum of 4 in pyridine- $d_{5}$. \# indicates solvent residual peaks. Figure S3. ${ }^{1} \mathrm{H}-{ }^{1} \mathrm{H}$ COSY NMR spectrum of 4 in pyridine- $d_{5}$. Figure S4. ${ }^{1} \mathrm{H}$ NMR spectrum of 5 in pyridine- $d_{5} .{ }^{*}$ indicates solvent residual peaks and \# stands for water residual. Figure S5. ${ }^{13} \mathrm{C}$ NMR spectrum of 5 in pyridine- $d_{5} .{ }^{*}$ indicates solvent residual peaks. Figure S6. ${ }^{1} \mathrm{H}^{-}{ }^{1} \mathrm{H}$ COSY NMR spectrum of 5 in pyridine- $d_{5}$.

Author Contributions: Conceptualization, T.K.; methodology, T.K.; investigation, T.K., W.S. and A.T.; writing—original draft preparation, T.K.; writing—review and editing, W.S. and T.G.; visualization, A.T.; supervision, T.G.; funding acquisition, T.G. All authors have read and agreed to the published version of the manuscript.

Funding: This research was funded by National Science Centre, Poland under Grant No. 2016/21/B/ NZ9/00783.

Institutional Review Board Statement: Not applicable.

Informed Consent Statement: Not applicable. 


\section{Data Availability Statement: Not applicable.}

Acknowledgments: This study was supported by the National Science Centre, Poland under Grant No. 2016/21/B/NZ9/00783 and the European Fund Regional Development Fund No. UDAPOIG.02.01.00-30-182/09. The authors thank Beata Kwiatkowska and Rita Kuba for excellent technical assistance.

Conflicts of Interest: The authors declare no conflict of interest

Sample Availability: Samples of the compounds 3, 4, and 5 are available from the authors.

\section{References}

1. Rodríguez-Morgade, M.S.; Stuzhin, P.A. The chemistry of porphyrazines: An overview. J. Porphyrins Phthalocyanines 2004, 8, 1129-1165. [CrossRef]

2. Fuchter, M.J.; Zhong, C.; Zong, H.; Hoffman, B.M.; Barrett, A.G.M. Porphyrazines: Designer Macrocycles by Peripheral Substituent Change. Aust. J. Chem. 2008, 61, 235-255. [CrossRef]

3. Belviso, S.; Ricciardi, G.; Lelj, F.; Scolaro, L.M.; Bencini, A.; Carbonera, C. Inducing asymmetry in free-base, MnIII, NiII and CuII (ethylsulfanyl)porphyrazines: Synthetic aspects and spectro-electrochemical implications. J. Chem. Soc. Dalton Trans. 2001, 1143-1150. [CrossRef]

4. Belviso, S.; Giugliano, A.; Amati, M.; Ricciardi, G.; Lelj, F.; Scolaro, L.M. Two-electron reduction of alkyl(sulfanyl)porphyrazines: A route to free-base and peripherally metallated asymmetric porphyrazines. Dalton Trans. 2003, 305-312. [CrossRef]

5. Belviso, S.; Capasso, A.; Santoro, E.; Najafi, L.; Lelj, F.; Superchi, S.; Casarini, D.; Villani, C.; Spirito, D.; Bellani, S.; et al. Thioethyl-Porphyrazine/Nanocarbon Hybrids for Photoinduced Electron Transfer. Adv. Funct. Mater. 2018, $28,1705418$. [CrossRef]

6. $\quad$ Lochman, L.; Machacek, M.; Miletin, M.; Uhlířová, Š.; Lang, K.; Kirakci, K.; Zimcik, P.; Novakova, V. Red-Emitting Fluorescence Sensors for Metal Cations: The Role of Counteranions and Sensing of SCN- in Biological Materials. ACS Sens. 2019, 4, 1552-1559. [CrossRef]

7. Cao, L.; Yang, C.; Zhang, B.; Lv, K.; Li, M.; Deng, K. Synergistic photocatalytic performance of cobalt tetra(2-hydroxymethyl-1,4dithiin)porphyrazine loaded on zinc oxide nanoparticles. J. Hazard. Mater. 2018, 359, 388-395. [CrossRef]

8. Belviso, S.; Santoro, E.; Penconi, M.; Righetto, S.; Tessore, F. Thioethyl Porphyrazines: Attractive Chromophores for Second-Order Nonlinear Optics and DSSCs. J. Phys. Chem. C 2019, 123, 13074-13082. [CrossRef]

9. Yuzhakova, D.V.; Lermontova, S.A.; Grigoryev, I.S.; Muravieva, M.S.; Gavrina, A.I.; Shirmanova, M.V.; Balalaeva, I.V.; Klapshina, L.G.; Zagaynova, E.V. In vivo multimodal tumor imaging and photodynamic therapy with novel theranostic agents based on the porphyrazine framework-chelated gadolinium (III) cation. Biochim. Biophys. Acta Gen. Subj. 2017, 1861, 3120-3130. [CrossRef]

10. Kunt, H.; Gonca, E. Synthesis and characterization of novel metal-free and metallo-porphyrazines with eight 3-thiopropylpentaflu orobenzoate units. Polyhedron 2012, 38, 218-223. [CrossRef]

11. Gonca, E. Metallo-porphyrazines with eight [5-thiopentyl 3,4,5-tris(benzyloxy)benzoate] groups: Synthesis, characterization, aggregation, and solubility behavior. J. Mol. Struct. 2017, 1130, 10-18. [CrossRef]

12. Gonca, E. New soluble porphyrazine derivatives containing electron-rich substituents. J. Coord. Chem. 2013, 66, 1720-1729. [CrossRef]

13. Yoshida, T.; Furuyama, T.; Kobayashi, N. Synthesis and optical properties of tetraazaporphyrin phosphorus(V) complexes with electron-rich heteroatoms. Tetrahedron Lett. 2015, 56, 1671-1674. [CrossRef]

14. Fernandez-Ariza, J.; Urbani, M.; Rodriguez-Morgade, M.S.; Torres, T. Panchromatic Photosensitizers Based on Push-Pull, Unsymmetrically Substituted Porphyrazines. Chem. A Eur. J. 2017, 24, 2618-2625. [CrossRef]

15. Tuncer, S.; Koca, A.; Gul, A.; Avciata, U. Synthesis, characterization, electrochemistry and spectroelectrochemistry of novel soluble porphyrazines bearing unsaturated functional groups. Dye Pigment. 2012, 92, 610-618. [CrossRef]

16. Belviso, S.; Amati, M.; Rossano, R.; Crispini, A.; Lelj, F. Non-symmetrical aryl- and arylethynyl-substituted thioalkylporphyrazines for optoelectronic materials: Synthesis, properties, and computational studies. Dalton Trans. 2014, 44, $2191-2207$. [CrossRef] [PubMed]

17. Falkowski, M.; Rebis, T.; Kryjewski, M.; Popenda, L.; Lijewski, S.; Jurga, S.; Mielcarek, J.; Milczarek, G.; Goslinski, T. An enhanced electrochemical nanohybrid sensing platform consisting of reduced graphene oxide and sulfanyl metalloporphyrazines for sensitive determination of hydrogen peroxide and l-cysteine. Dye Pigment. 2017, 138, 190-203. [CrossRef]

18. Falkowski, M.; Rebis, T.; Piskorz, J.; Popenda, L.; Jurga, S.; Mielcarek, J.; Milczarek, G.; Goslinski, T. Multiwalled carbon nanotube/sulfanyl porphyrazine hybrids deposited on glassy carbon electrode-Effect of nitro peripheral groups on electrochemical properties. J. Porphyrins Phthalocyanines 2017, 21, 295-301. [CrossRef]

19. Falkowski, M.; Rebis, T.; Piskorz, J.; Popenda, L.; Jurga, S.; Mielcarek, J.; Milczarek, G.; Goslinski, T. Improved electrocatalytic response toward hydrogen peroxide reduction of sulfanyl porphyrazine/multiwalled carbon nanotube hybrids deposited on glassy carbon electrodes. Dye Pigment 2016, 134, 569-579. [CrossRef] 
20. Koczorowski, T.; Rębiś, T.; Szczolko, W.; Antecka, P.; Teubert, A.; Milczarek, G.; Goslinski, T. Reduced graphene oxide/iron(II) porphyrazine hybrids on glassy carbon electrode for amperometric detection of NADH and L-cysteine. J. Electroanal. Chem. 2019, 848. [CrossRef]

21. Rębiś, T.; Falkowski, M.; Milczarek, G.; Goslinski, T. Electrocatalytic NADH Sensing using Electrodes Modified with 2-[2-(4Nitrophenoxy)ethoxy]ethylthio-Substituted Porphyrazine/Single-Walled Carbon Nanotube Hybrids. ChemElectroChem 2020, 7 , 2838-2850. [CrossRef]

22. Piskorz, J.; Lijewski, S.; Gierszewski, M.; Gorniak, K.; Sobotta, L.; Wicher, B.; Tykarska, E.; Düzgüneş, N.; Konopka, K.; Sikorski, M.; et al. Sulfanyl porphyrazines: Molecular barrel-like self-assembly in crystals, optical properties and in vitro photodynamic activity towards cancer cells. Dye Pigment 2017, 136, 898-908. [CrossRef]

23. Piskorz, J.; Mlynarczyk, D.T.; Szczolko, W.; Konopka, K.; Düzgüneş, N.; Mielcarek, J. Liposomal formulations of magnesium sulfanyl tribenzoporphyrazines for the photodynamic therapy of cancer. J. Inorg. Biochem. 2018, 184, 34-41. [CrossRef] [PubMed]

24. Sobotta, L.; Skupin-Mrugalska, P.; Piskorz, J.; Mielcarek, J. Porphyrinoid photosensitizers mediated photodynamic inactivation against bacteria. Eur. J. Med. Chem. 2019, 175, 72-106. [CrossRef] [PubMed]

25. Kabay, N.; Baygu, Y.; Alpoguz, H.K.; Kaya, A.; Gök, Y. Synthesis and characterization of porphyrazines as novel extractants for the removal of $\mathrm{Ag}(\mathrm{I})$ and $\mathrm{Hg}(\mathrm{II})$ from aqueous solution. Dye Pigment 2013, 96, 372-376. [CrossRef]

26. Liu, Y.; Zhou, X.; Zhang, Z.; Zhang, B.; Deng, K. Effect of carrier and axial ligand on the photocatalytic activity of cobalt thioporphyrazine. Chin. J. Catal. 2017, 38, 330-336. [CrossRef]

27. Yang, C.; Gao, L.; Zhang, B.; Zhang, Z.; Deng, K. Uniform zinc thioporphyrazine nanosphere by self-assembly and the photocatalytic performance. J. Porphyrins Phthalocyanines 2018, 22, 868-876. [CrossRef]

28. Zhang, Z.; Wen, X.; Deng, K.; Zhang, B.; Lv, K.; Sun, J. Photodegradation of rhodamine B with molecular oxygen catalyzed by a novel unsymmetrical iron porphyrazine under simulated sunlight. Catal. Sci. Technol. 2013, 3, 1415-1422. [CrossRef]

29. Yang, C.; Sun, J.; Deng, K.; Wang, D. Synthesis and photocatalytic properties of iron(II)tetramethyl- tetra(1,4-dithiin)porphyrazine. Catal. Commun. 2008, 9, 321-326. [CrossRef]

30. Su, R.; Sun, J.; Sun, Y.; Deng, K.; Cha, D.; Wang, D. Oxidative degradation of dye pollutants over a broad pH range using hydrogen peroxide catalyzed by $\mathrm{FePz}(\mathrm{dtnCl}) 4$. Chemosphere 2009, 77, 1146-1151. [CrossRef]

31. Tang, J.; Chen, L.; Sun, J.; Lv, K.; Deng, K. Synthesis and properties of iron(II) tetra(1,4-dithiin)porphyrazine bearing peripheral long-chain alkyl group of active end-bromine. Inorg. Chem. Commun. 2010, 13, 236-239. [CrossRef]

32. Wieczorek, E.; Mlynarczyk, D.T.; Kucinska, M.; Dlugaszewska, J.; Piskorz, J.; Popenda, L.; Szczolko, W.; Jurga, S.; Murias, M.; Mielcarek, J.; et al. Photophysical properties and photocytotoxicity of free and liposome-entrapped diazepinoporphyrazines on LNCaP cells under normoxic and hypoxic conditions. Eur. J. Med. Chem. 2018, 150, 64-73. [CrossRef] [PubMed]

33. Mlynarczyk, D.T.; Lijewski, S.; Falkowski, M.; Piskorz, J.; Szczolko, W.; Sobotta, L.; Stolarska, M.; Popenda, L.; Jurga, S.; Konopka, K.; et al. Dendrimeric Sulfanyl Porphyrazines: Synthesis, Physico-Chemical Characterization, and Biological Activity for Potential Applications in Photodynamic Therapy. ChemPlusChem 2016, 81, 460-470. [CrossRef] [PubMed]

34. Mlynarczyk, D.T.; Dlugaszewska, J.; Falkowski, M.; Popenda, L.; Kryjewski, M.; Szczolko, W.; Jurga, S.; Mielcarek, J.; Goslinski, T. Tribenzoporphyrazines with dendrimeric peripheral substituents and their promising photocytotoxic activity against Staphylococcus aureus. J. Photochem. Photobiol. B Biol. 2020, 204, 111803. [CrossRef] [PubMed]

35. Mlynarczyk, D.T.; Piskorz, J.; Popenda, L.; Stolarska, M.; Szczolko, W.; Konopka, K.; Jurga, S.; Sobotta, L.; Mielcarek, J.; Düzgüneş, N.; et al. S-seco-porphyrazine as a new member of the seco-porphyrazine family-Synthesis, characterization and photocytotoxicity against cancer cells. Bioorg. Chem. 2020, 96, 103634. [CrossRef]

36. Lijewski, S.; Gierszewski, M.; Sobotta, L.; Piskorz, J.; Kordas, P.; Kucinska, M.; Baranowski, D.; Gdaniec, Z.; Murias, M.; Karolczak, J.; et al. Photophysical properties and photochemistry of a sulfanyl porphyrazine bearing isophthaloxybutyl substituents. Dye Pigment 2015, 113, 702-708. [CrossRef]

37. Gierszewski, M.; Falkowski, M.; Sobotta, L.; Stolarska, M.; Popenda, L.; Lijewski, S.; Wicher, B.; Burdzinski, G.; Karolczak, J.; Jurga, S.; et al. Porphyrazines with peripheral isophthaloxyalkylsulfanyl substituents and their optical properties. J. Photochem. Photobiol. A Chem. 2015, 307-308, 54-67. [CrossRef]

38. Falkowski, M.; Kucinska, M.; Piskorz, J.; Wieczorek-Szweda, E.; Popenda, L.; Jurga, S.; Sikora, A.; Mlynarczyk, D.T.; Murias, M.; Marszall, M.P.; et al. Synthesis of sulfanyl porphyrazines with bulky peripheral substituents-Evaluation of their photochemical properties and biological activity. J. Photochem. Photobiol. A Chem. 2021, 405, 112964. [CrossRef]

39. Kucinska, M.; Skupin-Mrugalska, P.; Szczolko, W.; Sobotta, L.; Sciepura, M.; Tykarska, E.; Wierzchowski, M.; Teubert, A.; Fedoruk-Wyszomirska, A.; Wyszko, E.; et al. Phthalocyanine Derivatives Possessing 2-(Morpholin-4-yl)ethoxy Groups As Potential Agents for Photodynamic Therapy. J. Med. Chem. 2015, 58, 2240-2255. [CrossRef] [PubMed]

40. Dlugaszewska, J.; Szczolko, W.; Koczorowski, T.; Skupin-Mrugalska, P.; Teubert, A.; Konopka, K.; Kucinska, M.; Murias, M.; Düzgüneş, N.; Mielcarek, J.; et al. Antimicrobial and anticancer photodynamic activity of a phthalocyanine photosensitizer with $\mathrm{N}$-methyl morpholiniumethoxy substituents in non-peripheral positions. J. Inorg. Biochem. 2017, 172, 67-79. [CrossRef]

41. Kucinska, M.; Plewinski, A.; Szczolko, W.; Kaczmarek, M.; Goslinski, T.; Murias, M. Modeling the photodynamic effect in 2D versus 3D cell culture under normoxic and hypoxic conditions. Free Radic. Biol. Med. 2021, 162, 309-326. [CrossRef] [PubMed]

42. Rak, J.; Pouckova, P.; Benes, J.; Vetvicka, D. Drug Delivery Systems for Phthalocyanines for Photodynamic Therapy. Anticancer Res. 2019, 39, 3323-3339. [CrossRef]

43. Ghosh, S.; Carter, K.A.; Lovell, J.F. Liposomal formulations of photosensitizers. Biomaterials 2019, 218, 119341. [CrossRef] 
44. Chelminiak-Dudkiewicz, D.; Rybczynski, P.; Smolarkiewicz-Wyczachowski, A.; Mlynarczyk, D.T.; Wegrzynowska-Drzymalska, K.; Ilnicka, A.; Goslinski, T.; Marszałł, M.P.; Ziegler-Borowska, M. Photosensitizing potential of tailored magnetite hybrid nanoparticles functionalized with levan and zinc (II) phthalocyanine. Appl. Surf. Sci. 2020, 524, 146602. [CrossRef] [PubMed]

45. Aksenova, N.A.; Savko, M.A.; Uryupina, O.Y.; Roldugin, V.I.; Timashev, P.S.; Kuz'Min, P.G.; Shafeev, G.A.; Solov'Eva, A.B. Effect of the preparation method of silver and gold nanoparticles on the photosensitizing properties of tetraphenylporphyrin-amphiphilic polymer-nanoparticle systems. Russ. J. Phys. Chem. A 2017, 91, 124-129. [CrossRef]

46. Bera, K.; Maiti, S.; Maity, M.; Mandal, C.; Maiti, N.C. Porphyrin-Gold Nanomaterial for Efficient Drug Delivery to Cancerous Cells. ACS Omega 2018, 3, 4602-4619. [CrossRef] [PubMed]

47. Setaro, F.; Wennink, J.W.H.; Mäkinen, P.I.; Holappa, L.; Trohopoulos, P.N.; Ylä-Herttuala, S.; Van Nostrum, C.F.; De La Escosura, A.; Torres, T. Amphiphilic phthalocyanines in polymeric micelles: A supramolecular approach toward efficient third-generation photosensitizers. J. Mater. Chem. B 2020, 8, 282-289. [CrossRef]

48. Ziental, D.; Czarczynska-Goslinska, B.; Mlynarczyk, D.T.; Glowacka-Sobotta, A.; Stanisz, B.; Goslinski, T.; Sobotta, L. Titanium Dioxide Nanoparticles: Prospects and Applications in Medicine. Nanomaterials 2020, 10, 387. [CrossRef]

49. Musial, J.; Krakowiak, R.; Mlynarczyk, D.T.; Goslinski, T.; Stanisz, B.J. Titanium Dioxide Nanoparticles in Food and Personal Care Products-What Do We Know about Their Safety? Nanomaterials 2020, 10, 1110. [CrossRef]

50. Lü, X.-F.; Li, J.; Wang, C.; Duan, M.-Y.; Luo, Y.; Yao, G.-P.; Wang, J.-L. Enhanced photoactivity of CuPp-TiO2 photocatalysts under visible light irradiation. Appl. Surf. Sci. 2010, 257, 795-801. [CrossRef]

51. Forsyth, T.P.; Williams, D.B.G.; Montalban, A.G.; Stern, C.L.; Barrett, A.G.M.; Hoffman, B.M. A Facile and Regioselective Synthesis of Trans-Heterofunctionalized Porphyrazine Derivatives. J. Org. Chem. 1998, 63, 331-336. [CrossRef]

52. Linstead, R.P.; Whalley, M. 944. Conjugated macrocylces. Part XXII. Tetrazaporphin and its metallic derivatives. J. Chem. Soc. 1952, 1952, 4839-4846. [CrossRef]

53. Roncucci, G.; Dei, D.; De Filippis, M.P.; Fantetti, L.; Masini, I.; Cosimelli, B.; Jori, G. Zinc-Phthalocyanines and Corresponding Conjugates, Their Preparation and Use in Photodynamic Therapy and as Diagnostic Agents. U.S. Patent 5,965,598, 12 October 1999.

54. Koczorowski, T.; Ber, J.; Sokolnicki, T.; Teubert, A.; Szczolko, W.; Goslinski, T. Electrochemical and catalytic assessment of peripheral bromoaryl-substituted manganese and iron porphyrazines. Dye Pigment 2020, 178, 108370. [CrossRef]

55. Tuncer, S.; Koca, A.; Gül, A.; Avciata, U. 1,4-Dithiaheterocycle-fused porphyrazines: Synthesis, characterization, voltammetric and spectroelectrochemical properties. Dye Pigment 2009, 81, 144-151. [CrossRef]

56. Fuchter, M.J.; Beall, L.S.; Baum, S.M.; Montalban, A.G.; Sakellariou, E.G.; Mani, N.S.; Miller, T.; Vesper, B.J.; White, A.J.; Williams, D.J.; et al. Synthesis of porphyrazine-octaamine, hexamine and diamine derivatives. Tetrahedron 2005, 61, 6115-6130. [CrossRef]

57. Kryjewski, M.; Tykarska, E.; Rębiś, T.; Dlugaszewska, J.; Ratajczak, M.; Teubert, A.; Gapiński, J.; Patkowski, A.; Piskorz, J.; Milczarek, G.; et al. Porphyrazine with bulky 2-(1-adamantyl)-5-phenylpyrrol-1-yl periphery tuning its spectral and electrochemical properties. Polyhedron 2015, 98, 217-223. [CrossRef]

58. Rębiś, T.; Lijewski, S.; Nowicka, J.; Popenda, L.; Sobotta, L.; Jurga, S.; Mielcarek, J.; Milczarek, G.; Goslinski, T. Electrochemical properties of metallated porphyrazines possessing isophthaloxybutylsulfanyl substituents: Application in the electrocatalytic oxidation of hydrazine. Electrochim. Acta 2015, 168, 216-224. [CrossRef]

59. Hajri, A.; Touaiti, S.; Jamoussi, B. Preparation of Organic Zn-Phthalocyanine-Based Semiconducting Materials and Their Optical and Electrochemical Characterization. Adv. Optoelectron. 2013, 2013, 321563. [CrossRef]

60. Pommerehne, J.; Vestweber, H.; Guss, W.; Mahrt, R.F.; Bässler, H.; Porsch, M.; Daub, J. Efficient two layer leds on a polymer blend basis. Adv. Mater. 1995, 7, 551-554. [CrossRef]

61. Sakamoto, K.; Furuya, N.; Soga, H.; Yoshino, S. Cyclic voltammetry of non-peripheral thioaryl substituted phthalocyanines. Dye Pigment 2013, 96, 430-434. [CrossRef]

62. Sułek, A.; Pucelik, B.; Kuncewicz, J.; Dubin, G.; Dabrowski, J.M. Sensitization of TiO2 by halogenated porphyrin derivatives for visible light biomedical and environmental photocatalysis. Catal. Today 2019, 335, 538-549. [CrossRef]

63. Oliveira, D.F.; Batista, P.S.; Muller, P.S.; Velani, V.; França, M.D.; De Souza, D.R.; Machado, A.E. Evaluating the effectiveness of photocatalysts based on titanium dioxide in the degradation of the dye Ponceau 4R. Dye Pigment 2012, 92, 563-572. [CrossRef]

64. Kozlov, N.K.; Natashina, U.A.; Tamarov, K.P.; Gongalsky, M.B.; Solovyev, V.V.; Kudryavtsev, A.A.; Sivakov, V.; Osminkina, L.A. Recycling of silicon: From industrial waste to biocompatible nanoparticles for nanomedicine. Mater. Res. Express 2017, 4, 095026. [CrossRef]

65. Sobotta, L.; Fita, P.; Szczolko, W.; Wrotynski, M.; Wierzchowski, M.; Goslinski, T.; Mielcarek, J. Functional singlet oxygen generators based on porphyrazines with peripheral 2,5-dimethylpyrrol-1-yl and dimethylamino groups. J. Photochem. Photobiol. A Chem. 2013, 269, 9-16. [CrossRef] 